\title{
PENGEMBANGAN PETUNJUK PRAKTIKUM IPA BERBASIS MODEL INKUIRI TERBIMBING UNTUK SISWA SMP/MTS KELAS VIII
}

\author{
K. M. Indriyana, N. M. Pujani, K. Selamet \\ Program Studi S1 Pendidikan IPA \\ Universitas Pendidikan Ganesha \\ Singaraja, Indonesia \\ e-mail: \{kadek.mega.indriyana, made.pujani, kompyang selamet\}@undiksha.ac.id
}

\begin{abstract}
Abstrak
Penelitian ini bertujuan mengembangkan petunjuk praktikum IPA berbasis model inkuiri terbimbing untuk siswa SMP/MTs kelas VIII pada materi tekanan zat dan penerapannya dalam kehidupan sehari-hari yang valid serta praktis digunakan dalam pembelajaran. Jenis penelitian ini adalah penelitian pengembangan $(R \& D)$ dengan metode pengembangan fourD yaitu Define, Design, Develop, dan Disseminate. Pengembangan pada penelitian ini dibatasi sampai tahap develop (uji kepraktisan) karena keterbatasan waktu, biaya serta kemampuan peneliti. Pengujian desain, isi dan bahasa pada petunjuk praktikum IPA berbasis model inkuiri terbimbing dilakukan oleh dua orang ahli kependidikan IPA. Produk penelitian ini diuji secara terbatas dengan responden sebanyak dua belas orang siswa dan dua orang guru. Data validasi serta kepraktisan di analisis deskriptif. Hasil penelitian menunjukan bahwa (1) petunjuk praktikum IPA hasil pengembangan memiliki karakteristik yaitu setiap tahapan dalam kegiatan praktikum sesuai dengan fese-fese dalam model inkuiri terbimbing, (2) nilai validasi desain, isi dan bahasa petunjuk praktikum IPA oleh para ahli adalah 3,52 yang termasuk dalam kategori sangat valid, (3) hasil uji keterbacaan diperoleh hasil sebesar 3,63 yang termasuk dalam kategori sangat paham, (4) hasil respon siswa dan guru terhadap keterlaksanaan diperoleh skor rata-rata sebesar 94\% dan 3,69 dalam kategori sangat terlaksana. Berdasarkan hasil analisis data uji keterbacaan dan uji keterlaksanaan dapat disimpulkan bahwa petunjuk praktikum IPA hasil pengembangan dikategorikan praktis.
\end{abstract}

Kata kunci: petunjuk praktikum IPA, model four-D, model inkuiri terbimbing.

\begin{abstract}
This research aims to develop science practicum instructions based on guided inquiry model for class VIII Middle School / MTs students on material pressure material and its application in daily life that is valid and practical used in learning. This type of research is development research $(R \& D)$ with a four-D development method includes four stages Define, Design, Develop, and Disseminate. The development of this research is limited to the stage of develop (practicality test) because of the limited time, cost and ability of researchers. Design, content and language testing on guided inquiry-based science practice instructionswas carried out by 2 science education experts. The product of this study was tested on a limited basis with respondents as many as 12 students and 2 teachers. Validation test and practicality was processed by descriptive analysis. The results showed that (1) the science practicum instruction of the development result had characteristics, namely each stage in the practicum activities in accordance with the features in the guided inquiry model, (2) the value of design validation, content and language of science practicum instructions by experts was 3.52 which included in the very valid category, (3) the results of the readability test obtained results of 3.63 included in the category of very understand (4) the results of student and teacher responses to implementation obtained an average score of $94 \%$ and 3.69 in the very accomplished category. Based on the results of the analysis of the readability test data and the implementation test, it can be concluded that the science practicum instructions from the development results are categorized as practical.
\end{abstract}

Keywords: science practicum instructions, four-D model, guided inquiry model. 


\section{PENDAHULUAN}

Salah satu mata pelajaran penting dalam kurikulum 2013 adalah mata pelajaran IPA terpadu. IPA didefinisikan sebagai suatu kumpulan teori yang sistematis, penerapannya secara umum terbatas pada gejala-gejala alam, lahir dan berkembang melalui metode ilmiah seperti observasi dan eksperimen serta menuntut sikap ilmiah seperti rasa ingin tahu, terbuka, jujur, dan sebagainya (Trianto, 2010). Merujuk pada pengertian IPA, pada hakikatnya IPA mencakup dua hal yaitu IPA sebagai proses dan IPA sebagai produk (Suastra, 2013). Pembelajaran IPA menuntut peserta didik untuk memiliki pengetahuan dan keterampilan proses sains. Peserta didik dituntut untuk dapat melakukan percobaan yang di dalamnya terdapat merumuskan masalah, menyusun hipotesis dan mengujinya, menentukan variabel, mengumpulkan data, mengolah dan menafsirkan data, menarik kesimpulan hingga mengkomunikasikan hasil percobaan baik lisan maupun tertulis.

Upaya pemerintah dalam meningkatkan keterampilan proses sains dalam pembelajaran IPA diantaranya adalah (1) penetapan Permendikbud No 21 Tahun 2016 tentang Standar Isi Pendidikan Dasar dan Menengah, (2) penetapan Permendikbud No 22 Tahun 2016 tentang Standar Proses Pendidikan Dasar dan Menengah, (3) penyempurnaan kurikulum 2013 yang menuntut siswa belajar dengan pendekatan saintifik. Wardani et al, (2016) mengatakan upaya lain yang dilakukan oleh pemerintah dalam meningkatkan keterampilan proses adalah pengadaan perangkat pembelajaran dan buku referensi lainnya, penataran guru tentang proses belajar mengajar serta kegiatan musyawarah guru mata pelajaran.

Kenyataannya keterampilan proses sains siswa masih rendah. Hal itu dibuktikan dengan penelitian yang dilakukan oleh Rahayu dan Anggraeni (2017) yang mendapatkan hasil bahwa keterampilan proses sains siswa secara keseluruhan masih rendah dengan nilai rata-rata sebesar 9,8. Hal yang sama juga melatar belakangi penelitian yang dilakukan oleh Novianti (2017) yang menyatakan bahwa keterampilan proses sains peserta didik masih rendah terlihat dari kemampuan peserta didik pada saat merangkai alat dan melakukan percobaan secara mandiri masih sulit saat ujian praktik kelas IX tahun pelajaran 2016/2017.

Rendahnya keterampilan proses siswa dalam pembelajaran IPA disebabkan karena proses pembelajaran yang berlangsung belum sesuai dengan karakteristik dari pembelajaran IPA. Dalam Permendikbud No 103 Tahun 2014 menguraikan bahwa pembelajaran pada kurikulum 2013 menggunakan pendekatan saintifik dengan beberapa model pembelajaran diantaranya discovery learning, project based learning, problem based learning dan inquiry learning. Hal yang sama juga disampaikan oleh Fransiska et al, (2019) yang mengatakan salah satu upaya mengembangkan keterampilan proses sains siswa adalah penggunaan model pembelajaran yang mampu menggerakkan siswa untuk menumbuhkan keterampilan proses sains yang meliputi kemampuan mengamati, menafsirkan, meramalkan, menggunakan alat dan bahan, menerapkan konsep, merencanakan kegiatan, berkomunikasi dan bertanya. Namun dalam pelaksanaannya guru cenderung kurang maksimal dalam menerapkan model pada pembelajaran IPA.

Kurangnya penerapan model dalam pembelajaran IPA disebabkan karena perangkat pembelajaran berbasis model jarang dimiliki oleh guru. Salah satunya adalah tidak ada petunjuk praktikum yang sesuai dengan karakteristik pendekatan saintifik. Hal tersebut sejalan dengan hasil penelitian yang dilakukan oleh Simamora \& Sudarma (2017) tentang analisis perangkat pembelajaran kurikulum 2013. Hasil penelitian menunjukan bahwa kualitas LKS guru secara kualitatif masih sangat kurang. Secara garis besar, LKS yang dibuat oleh guru belum sesuai dengan teori pembuatan LKS. Tidak adanya LKS/petunjuk praktikum menyebabkan pembelajaran dengan metode praktikum jarang dilakukan oleh guru. Praktikum adalah cara penyajian pelajaran, yaitu siswa melakukan percobaan dengan mengalami dan membuktikan sendiri sesuatu yang dipelajari (Djamarah \& Zain, 2006). Hal ini 
sesuai dengan hasil observasi yang dilakukan di SMP N 2 Singaraja. Hasil observasi menunjukan bahwa kegiatan praktikum jarang dilakukan bukan karena tidak adanya sarana (laboratorium IPA) yang menunjang, melainkan perangkat berupa petunjuk dalam melakukan praktikum yang masih kurang. Petunjuk praktikum yang digunakan guru saat melakukan kegiatan praktikum hanya berpacu pada buku pegangan siswa serta LKS hasil percetakan. Isi dari petunjuk praktikum yang terdapat pada buku siswa serta LKS hasil percetakan belum sesuai dengan karakteristik pembelajaran 5M. Hal itu dibuktikan dengan tidak adanya tahapan bagi siswa untuk membuat rumusan masalah serta hipotesis mengenai percobaan yang akan dilakukannya. Selain itu, petunjuk praktikum yang tercantum pada buku siswa dan LKS hasil percetakan tersebut sering kali tidak begitu menuntun siswa dalam melakukan kegiatan praktikum, sehingga peserta didik hanya menguasai pemahaman konsep melalui kaji materi dan soal-soal yang tertera pada LKS, tidak berdasarkan keterampilan proses dalam pembelajaran IPA. Hal tersebut membuat pencapaian hasil belajar siswa pun menjadi terbatas pada aspek pengetahuan (kognitif) saja, tetapi belum banyak mengalami pengembangan aspek sensori-motorik, psikososial (afektif), dan nilai-nilai (values).

Solusi yang dapat dilakukan untuk mengatasi permasalahan dalam pelaksanaan praktikum yaitu dikembangkan suatu petunjuk praktikum yang berisi materi IPA yang dapat menuntun siswa untuk melakukan praktikum dengan benar. Hal ini sesuai dengan penelitian yang dilakukan oleh Sofiani, et al (2018) yang mendapatkan hasil bahwa pengembangan petunjuk praktikum berbasis model inkuiri terbimbing memberikan reaksi positif pada siswa. Penelitian yang serupa juga dilakukan oleh Payudi, et al (2017) yang mendapatkan hasil bahwa LKS hasil pengembangan efektif untuk meningkatkan hasil belajar siswa dalam keterampilan proses sains. Mengingat pentingnya sebuah petunjuk praktikum untuk melatih keterampilan proses siswa dalam pembelajaran IPA, maka penting untuk dilakukan penelitian pengembangan petunjuk praktikum IPA berbasis model inkuiri terbimbing. Pembelajaran dengan menggunakan model inkuiri terbimbing menuntut siswa untuk memperoleh informasi ilmiah dengan jalan melakukan observasi dan /atau eksperimen untuk mencari jawaban pertanyaan atau memecahkan masalah yang telah dirumuskan dengan menggunakan kemampuan berpikir logis, analitis, dan kritis (Sadia, 2014).

Suryani \& Agung (2012), mengemukakan ada beberapa hal yang menjadi ciri utama strategi pembelajaran inkuiri diantaranya adalah (1) strategi inkuiri menekankan kepada aktivitas siswa secara maksimal untuk mencari dan menemukan, (2) seluruh aktivitas yang dilakukan siswa diarahkan untuk mencari dan menemukan sendiri dari sesuatu yang dipertanyakan, sehingga diharapkan dapat menumbuhkan sikap percaya diri (self-belief), (3) tujuan dari penggunaan strategi pembelajaran inkuiri adalah mengembangkan kemampuan intelektual sebagai bagian dari proses mental, akibatnya dalam pembelajaran inkuiri siswa tidak hanya dituntut agar menguasai pembelajaran, akan tetapi bagaimana mereka dapat menggunakan potensi yang dimilikinya.

Tujuan dari penelitian ini adalah menghasilkan petunjuk praktikum IPA berbasis model inkuiri terbimbing yang valid serta praktis digunakan dalam pembelajaran.

\section{METODE PENELITIAN}

Penelitian ini menggunakan metode penelitian pengembangan $(R \& D)$ dengan model 4-D. Model 4-D merupakan kepanjangan dari define, design, develop, dan dissemination yang diperkenalkan oleh Thiagarajan pada 1974 (dalam Prasetyo, 2015). Pada penelitian ini dibatasi sampai tahap develop karena keterbatasan waktu, biaya serta kemampuan peneliti.

Tahap define adalah tahap mengumpulkan informasi yang diperlukan (needs assessment). Tahap ini mencakup tiga langkah pokok yaitu (1) analisis ujung depan yaitu dengan melakukan wawancara untuk mengetahui kebutuhan di sekolah 
yang dijadikan tempat penelitian serta mengetahui karakteristik dari produk yang dikembangkan, (2) analisis kurikulum dilakukan dengan metode studi pustaka yaitu melakukan analisis silabus kurikulum 2013 untuk menentukan kompetensi dasar yang berkaitan dengan materi pada petunjuk praktikum yang dikembangkan, (3) perumusan tujuan kurikulum yaitu menentukan perubahan perilaku yang diharapkan setelah siswa melakukan pembelajaran menggunakan produk hasil pengembangan dengan berpacu pada kompetensi dasar yang dimuat dalam silabus kurikulum 2013 serta indikator yang diharapkan muncul dalam pembelajaran.

Tahap design adalah tahap merancang produk awal atau draf petunjuk praktikum IPA berbasis model inkuiri terbimbing. Pada tahap ini juga dirancang angket yang dijadikan instrumen dalam pengumpulan data. Angket yang digunakan peneliti berupa angket validasi produk, angket keterbacaan serta angket keterlaksanaan yang terdiri dari angket respon guru dan siswa.

Tahap develop adalah tahap untuk menghasilkan produk. Tahap ini dilakukan melalui dua langkah yaitu (1) validasi atau penilaian ahli (expert apprasial) yang disertai dengan revisi dan (2) uji kepraktisan yang disertai dengan revisi. Uji kepraktisan dilakukan pada siswa dengan sampel kecil berjumlah 12 orang dan 2 orang guru. Uji kepraktisan diperoleh dari data uji keterbacaan dan uji keterlaksanaan. Angket keterbacaan akan diberikan kepada siswa yang sudah mendapatkan materi sebelumya sedangkan angket keterlaksanaan akan diberikan pada siswa yang belajar menggunakan produk hasil pengembangan. Selain siswa, guru juga diberikan sebuah angket yaitu angket respon guru terhadap penggunaan produk hasil pengembangan. Angket respon ini diberikan setelah guru menerapkan pembelajaran menggunakan produk hasil pengembangan. Hasil dari pengisian angket diolah menggunakan teknik analisis perhitungan rata-rata menurut Arikunto (2006).

Data dikumpulkan dengan metode observasi, wawancara, studi pustaka,serta angket. Jenis data yang dikumpulkan berupa data kualitatif dan data kuantitatif. Data kualitatif dianalisis secara induktif sedangkan data kuantitatif diolah dengan analisis deskriptif.

\section{HASIL DAN PEMBAHASAN}

Pada penelitian ini telah dihasilkan petunjuk praktikum IPA berbasis model inkuiri terbimbing untuk siswa SMP/MTs kelas VIII pada materi tekanan zat dan penerapannya dalam kehidupan seharihari. Petunjuk praktikum yang dikembangkan sesuai dengan silabus pada kurikulum 2013 kelas VIII semester II. Berdasarkan kompetensi dasar pada silabus tersebut peneliti menyusun petunjuk praktikum sesuai dengan konsep esensial pada setiap kompetensi dasar dalam silabus. Total petunjuk praktikum yang dikembangkan sebanyak 6 petunjuk praktikum dengan judul kegiatan sebagai berikut (1) membuktikan tekanan pada benda padat, (2) tekanan hidrostatis, (3) hukum Archimedes, (4) hukum Pascal, (5) tekanan pada gas dan (6) aplikasi tekanan pada makhluk hidup (daya isap daun).

Pada tahap define telah dilaksanakan pra-penelitian untuk penetapan kebutuhan pengembangan (needs assessment) melalui wawancara dengan guru IPA dan juga studi pustaka. Hasil yang diperoleh pada tahap ini adalah (1) siswa ketika melakukan kegiatan praktikum berpatokan pada petunjuk praktikum yang terdapat dalam buku siswa terbitan kemendikbud revisi tahun 2017 serta LKS hasil percetakan. Hasil wawancara dengan guru juga menyebutkan petunjuk praktikum yang terdapat pada buku siswa terbitan kemendikbud serta LKS hasil percetakan kurang dapat menuntun siswa dalam melakukan kegiatan praktikum sesuai dengan pendekatan saintifik. (2) Berdasarkan hasil studi pustaka terhadap silabus 2013 peneliti memilih materi tekanan zat dan penerapannya dalam kehidupan sehari-hari dalam pengembangan petunjuk praktikum IPA. Pemilihan materi ini juga didasarkan atas karakteristik dari materi yang sangat diperlukan dan memungkinkan untuk dilakukan praktikum serta ketersediaan alat dan bahan di sekolah yang menunjang kegiatan praktikum. (3) Berdasarkan hasil 
analisis kompetensi dasar yang dilakukan, disusun sebelas tujuan praktikum yang akan dicapai oleh siswa ketika melakukan pembelajaran IPA menggunakan petunjuk praktikum hasil pengembangan. Hasil analisis kurikulum 2013 berlandaskan pada UU No. 20 tahun 2003 terhadap mata pelajaran IPA tingkat SMP/MTs kelas VIII dapat dilihat pada Tabel 1.

Tabel 1. Cuplikan Analisis Silabus Pada Materi tekanan Zat dan Penerapannya dalam Kehidupan Sehari-hari

\begin{tabular}{|c|c|c|}
\hline Mata Pelajaran & & IPA Terpadu \\
\hline Kompetensi Dasar & 3.8 & $\begin{array}{l}\text { Menjelaskan tekanan zat dan penerapannya dalam } \\
\text { kehidupan sehari-hari, termasuk tekanan darah, } \\
\text { osmosis, dan kapilaritas jaringan angkut pada } \\
\text { tumbuhan. }\end{array}$ \\
\hline & 4.8 & $\begin{array}{l}\text { Menyajikan data hasil percobaan untuk menyelidiki } \\
\text { tekanan zat cair pada kedalaman tertentu, gaya apung, } \\
\text { dan kapilaritas, misalnya dalam batang tumbuhan. }\end{array}$ \\
\hline Materi Pokok & 1. & Tekanan zat pada, cair dan gas \\
\hline & 2. & Tekanan darah \\
\hline & 3. & Osmosis \\
\hline & 4. & Gaya apung \\
\hline & 5. & Kapilaritas jaringan angkut pada tumbuhan \\
\hline Indikator & 3.8 .1 & $\begin{array}{l}\text { Siswa mampu menganalisis hubungan antara gaya dan } \\
\text { luas permukaan }\end{array}$ \\
\hline & 3.8 .2 & $\begin{array}{l}\text { Siswa mampu menganalisis faktor yang mempengaruhi } \\
\text { tekanan hidrostatis }\end{array}$ \\
\hline & 3.8 .3 & $\begin{array}{l}\text { Siswa mampu membuktikan hubungan antara gaya ke } \\
\text { atas dengan berat zat cair yang dipindahkan }\end{array}$ \\
\hline & 4.8 .1 & $\begin{array}{l}\text { Siswa mampu merancang alat sederhana dengan } \\
\text { konsep Hukum Pascal }\end{array}$ \\
\hline & 4.8 .2 & $\begin{array}{l}\text { Siswa terampil menyajikan data hasil percobaan dalam } \\
\text { diskusi kelas }\end{array}$ \\
\hline
\end{tabular}

Selanjutnya pengembangan petunjuk praktikum IPA dilanjutkan pada tahap design. Pada tahap ini telah dikembangkan draf awal petunjuk praktikum IPA berbasis model inkuiri terbimbing. Petunjuk praktikum IPA yang dikembangkan terdiri dari beberapa komponen utama diantaranya adalah (1) judul praktikum, (2) tujuan praktikum, (3) dasar teori, (4) fenomena, (5) perumusan masalah, (6) perumusan hipotesis, (7) alat dan bahan, (8) prosedur kerja, (9) tabel pengamatan, (10) analisis data, dan (11) kesimpulan. Selain perancangan komponen utama, petunjuk praktikum yang akan dikembangkan juga dilengkapi dengan komponen pendukung diantaranya adalah (1) cover, (2) kata pengantar, (3) daftar isi, (4) pedoman penggunaan petunjuk praktikum, (5) tata tertib di laboratorium IPA, (6) tips penggunaan alat, (7) simbol keselamatan kerja di laboratorium IPA, (8) rambu keselamatan kerja di laboratorium IPA, (9) daftar pustaka, dan (10) format penyusunan laporan hasil praktikum. Pada tahap design juga dirancang angket yang digunakan sebagai instrumen pengambilan data. Angket yang dirancang adalah angket validasi ahli yang terdiri dari dua puluh butir penilaian dengan rincian enam butir aspek desain/tampilan, sepuluh butir aspek isi, dan empat butir aspek bahasa. Angket keterbacaan yang terdiri dari lima belas butir pernyataan dengan rincian delapan butir syarat didaktik, empat butir syarat konstruksi dan tiga butir syarat teknik. Angket keterlaksanaan meliputi angket respon siswa yang terdiri dari sepuluh butir pernyataan dan angket respon guru yang terdiri dari tiga belas butir pernyataan.

Proses penyusunan draf petunjuk praktikum IPA berbasis model inkuiri 
terbimbing selanjutnya masuk dalam tahap develop. Pada tahap ini dilaksanakan proses validasi oleh dua orang ahli yaitu dosen pendidikan IPA. Angket yang digunakan berupa angket validasi dengan menggunakan skala likert 4. Proses validasi petunjuk praktikum IPA berbasis model inkuiri terbimbing sekaligus diikuti dengan sejumlah revisi hingga akhirnya siap diuji pada siswa dengan kelompok kecil. Adapun hasil validasi disajikan pada Tabel 2 .

Tabel 2. Hasil Validasi oleh Ahli

\begin{tabular}{ccc}
\hline No. & Aspek Validasi & $\overline{\boldsymbol{X}}$ \\
\hline 1 & Desain/tampilan & 3,42 \\
2 & Isi & 3,70 \\
3 & Bahasa & 3,40 \\
\hline & Rata-rata & $\mathbf{3 , 5 2}$ \\
\hline
\end{tabular}

Berdasarkan Tabel 2 hasil validasi petunjuk praktikum IPA berbasis model inkuiri terbimbing adalah 3,52. Hasil validasi yang diperoleh menyatakan bahwa petunjuk praktikum IPA berbasis model inkuiri terbimbing hasil pengembangan termasuk dalam kategori sangat valid sesuai dengan kriteria validasi analisis ratarata oleh Arikunto (2006).

Adapun beberapa revisi yang disarankan oleh ahli adalah menghapus beberapa gambar agar cover tak terlihat begitu ramai, menambahkan nama serta sumber dari setiap gambar yang ada, menambahkan daftar alat dan bahan pada setiap kegiatan, menambahkan satuan pada kolom pengamatan, memperbaiki beberapa kata yang salah ketik.

Pada uji keterbacaan siswa yang sudah pernah mendapatkan materi tekanan zat dan penerapannya dalam kehidupan sehari-hari diberikan instrumen berupa lembar keterbacaan dengan skala likert 4 . Instrumen disebarkan pada dua belas siswa kelas VIII. Adapun hasil uji keterbacaan disajikan pada Tabel 3.

Tabel 3. Hasil Uji Keterbacaan

\begin{tabular}{clc}
\hline No. & $\begin{array}{c}\text { Aspek } \\
\text { Keterbacaan }\end{array}$ & $\overline{\boldsymbol{X}}$ \\
\hline 1 & Syarat didaktik & 3,61 \\
2 & Syarat konstruksi & 3,60 \\
3 & Syarat teknik & 3,75 \\
\hline & Rata-rata & $\mathbf{3 , 6 3}$ \\
\hline
\end{tabular}

Berdasarkan analisis data uji
keterbacaan, diperoleh hasil uji keterbacaan sebesar 3,63 yang berarti bahwa petunjuk praktikum IPA berbasis model inkuiri terbimbing termasuk kategori sangat paham sesuai dengan kriteria keterbacaan analisis rata-rata oleh Arikunto (2006).

Pada uji keterlaksanaan siswa diberikan angket untuk merespon proses keterlaksanaan pembelajaran dengan menggunakan petunjuk praktikum IPA hasil pengembangan. Instrumen ini diberikan setelah uji coba selesai dilakukan. Instrumen yang diberikan berupa angket pernyataan dengan pilihan jawaban YA/TIDAK yang disertai dengan alasan atas pilihan jawaban. Jumlah item penilaian pada angket respon keterlaksanaan adalah 10 butir. Adapun hasil uji respon siswa terhadap keterlaksanaan pembelajaran menggunakan produk hasil pengembangan disajikan pada Tabel 4.

Tabel 4. Analisis Hasil Respon Siswa

\begin{tabular}{clc}
\hline No. & \multicolumn{1}{c}{ Pernyataan } & $\%$ \\
\hline 1 & $\begin{array}{l}\text { Saya selalu membaca fenomena pada setiap kegiatan dalam petunjuk } \\
\text { praktikum ini }\end{array}$ & 100 \\
2 & $\begin{array}{l}\text { Saya selalu membaca dasar teori pada setiap kegiatan dalam petunjuk } \\
\text { praktikum ini }\end{array}$ & 100 \\
3 & $\begin{array}{l}\text { Saya tidak selalu mencatat hal-hal penting pada kegiatan petunjuk } \\
\text { praktikum }\end{array}$ & 92 \\
4 & Saya selalu membuat rumusan masalah pada setiap kegiatan & 83
\end{tabular}




\begin{tabular}{clc}
\hline No. & \multicolumn{1}{c}{ Pernyataan } & $\%$ \\
\hline 5 & $\begin{array}{l}\text { Saya tidak selalu membuat hipotesis atas rumusan masalah yang telah } \\
\text { dibuat }\end{array}$ & 92 \\
6 & $\begin{array}{l}\text { Saya selalu menyiapkan alat dan bahan yang diperlukan dalam kegiatan } \\
\text { praktikum }\end{array}$ & 92 \\
7 & $\begin{array}{l}\text { Saya selalu melaksanakan kegiatan praktikum sesuai dengan langkah } \\
\text { kerja }\end{array}$ & 100 \\
8 & Ada beberapa tabel pengamatan yang tidak saya lengkapi dengan benar & 83 \\
9 & $\begin{array}{l}\text { Saya bisa menjawab pertanyaan pada petunjuk praktikum ini } \\
10\end{array}$ & $\begin{array}{l}\text { Saya selalu membuat kesimpulan pada setiap kegiatan yang telah } \\
\text { dilakukan }\end{array}$ \\
\hline
\end{tabular}

Berdasarkan analisis data angket respon siswa terhadap keterlaksanaan, diperoleh hasil sebesar $94 \%$ yang berarti bahwa petunjuk praktikum IPA berbasis model inkuiri terbimbing termasuk kategori sangat terlaksana sesuai dengan kriteria keterlaksanaan analisis rata-rata oleh Arikunto (2006).

Guru juga diberikan angket respon. Pengisian angket dilakukan oleh dua orang guru yang telah menggunakan petunjuk praktikum IPA hasil pengembangan. Instrumen yang digunakan berupa angket respon keterlaksanaan dengan skala likert 4. Jumlah pernyataan pada angket respon guru terdiri dari tiga belas butir. Hasil analisis angket respon guru terhadap keterlaksaan pembelajaran dengan menggunakan petunjuk praktikum IPA hasil pengembangan disajikan pada Tabel 5 .

\section{Tabel 5. Analisis Hasil Respon Guru}

\begin{tabular}{|c|c|c|}
\hline No. & Pernyataan & $\bar{X}$ \\
\hline 1 & $\begin{array}{l}\text { Saya senang melaksanakan kegiatan petunjuk praktikum ini dalam kegiatan } \\
\text { pembelajaran }\end{array}$ & 4,00 \\
\hline 2 & $\begin{array}{l}\text { Petunjuk praktikum ini sudah sesuai dengan langkah-langkah pembelajaran } \\
\text { inkuiri terbimbing }\end{array}$ & 3,00 \\
\hline 3 & $\begin{array}{l}\text { Petunjuk praktikum ini memudahkan saya untuk menuntun siswa dalam } \\
\text { melakukan kegiatan praktikum }\end{array}$ & 4,00 \\
\hline 4 & $\begin{array}{l}\text { Petunjuk praktikum ini bisa digunakan oleh siswa dengan kategori menengah } \\
\text { ke atas }\end{array}$ & 3,50 \\
\hline 5 & $\begin{array}{l}\text { Petunjuk praktikum ini bisa digunakan oleh siswa dengan kategori menengah } \\
\text { ke bawah }\end{array}$ & 3,50 \\
\hline 6 & $\begin{array}{l}\text { Prosedur kerja dalam petunjuk praktikum ini mudah dipahami sehingga dapat } \\
\text { dilakukan oleh siswa }\end{array}$ & 3,50 \\
\hline 7 & $\begin{array}{l}\text { Materi yang dibahas pada petunjuk praktikum ini merupakan materi/konsep } \\
\text { yang kontekstual }\end{array}$ & 4,00 \\
\hline 8 & $\begin{array}{l}\text { Setiap aktivitas dalam petunjuk praktikum ini memiliki tujuan yang dapat } \\
\text { dipahami }\end{array}$ & 4,00 \\
\hline 9 & Jumlah alokasi waktu ideal dengan kegiatan pada petunjuk praktikum & 3,50 \\
\hline 10 & Gambar yang disajikan pada petunjuk praktikum ini jelas dan menarik & 4,00 \\
\hline 11 & Jenis font/huruf yang digunakan dalam petunjuk praktikum ini mudah dibaca & 4,00 \\
\hline 12 & Tampilan petunjuk praktikum ini menarik & 3,50 \\
\hline 13 & $\begin{array}{l}\text { Penting untuk dibuat salah satu perangkat pembelajaran seperti petunjuk } \\
\text { praktikum ini }\end{array}$ & 3,50 \\
\hline \multicolumn{2}{|r|}{ Rata-rata } & 3 \\
\hline
\end{tabular}


$\begin{array}{cc}\text { Berdasarkan analisis angket respon } \\ \text { guru } & \text { terhadap } \quad \text { keterlaksanaan }\end{array}$ pembelajaran menggunakan petunjuk praktikum IPA hasil pengembangan, diperoleh skor rata-rata sebesar 3,69 yang berarti bahwa petunjuk praktikum IPA berbasis model inkuiri terbimbing termasuk kategori sangat terlaksana sesuai dengan kriteria keterlaksanaan analisis rata-rata oleh Arikunto (2006).

Berdasarkan hasil analisis data uji keterbacaan serta uji keterlaksanaan yang terdiri dari angket respon guru dan siswa dapat disimpulkan bahwa petunjuk praktikum IPA hasil pengembangan dapat dikategorikan praktis.

\section{PEMBAHASAN}

Petunjuk praktikum yang disusun dalam penelitian ini memiliki beberapa karakteristik yang membedakannya dengan petunjuk praktikum IPA lainnya. Setiap prosedur dalam petunjuk praktikum IPA ini mengikuti prosedur dari model pembelajaran inkuiri terbimbing. Hal itu dikarenakan model inkuiri terbimbing bertujuan untuk melatih kemampuan peserta didik untuk melakukan penelitian, menjelaskan fenomena, menemukan inti dan makna dari suatu permasalahan, dan memecahkan permasalahan dari suatu prsedur ilmiah yang dilakukannya secara mandiri (Sadia, 2014). Siswa akan lebih menjadi termotivasi ketika mereka belajar menemukan sesuatu oleh dirinya sendiri, daripada mendengarkan apa yang dikatakan oleh guru (Marheni \& Suardana, 2014). Hal tersebut juga seirama dengan penelitian yang dilakukan oleh Pariatna, et al (2015) yang menyebutkan bahwa model pembelajaran inkuiri terbimbing merupakan salah satu model pembelajaran inovatif yang berlandasakan paradigma konstruktivistik dan sesuai dengan hakikat sains sebagai proses dan produk.

Secara umum, petunjuk praktikum IPA berbasis model inkuiri terbimbing yang dirancang ini dapat dikatakan valid disebabkan karena komponen-komponen pada petunjuk praktikum IPA yang dikembangkan telah sesuai dengan indikator yang telah ditetapkan pada instrumen validasi. Produk juga dikatakan valid karena telah sesuai dengan analisis yang diperoleh pada tahap analisis kurikulum yaitu penyajian materi serta perumusan tujuan praktikum yang dikembangkan sesuai dengan kebutuhan di lapangan. Petunjuk praktikum IPA yang dikembangkan juga telah memenuhi validitas isi dan validitas konstruk. Wahyuni (2016) menyatakan LKS memenuhi validitas isi berarti dalam pengembangannya telah didasarkan atas teori-teori yang dijadikan pedoman dalam penyusunan LKS tersebut. LKS yang memenuhi validitas konstruksi berarti dalam pengembangannya telah memperhatikan keterkaitan antara komponen-komponen dalam LKS tersebut.

Pada uji kepraktisan data diperoleh dari uji keterbacaan dan keterlaksanaan. Hasil uji keterbacaan dinyatakan bahwa petunjuk praktikum IPA berbasis model inkuiri terbimbing termasuk dalam kategori sangat dipahami oleh siswa. Hasil keterbacaan diperoleh karena dalam pengembangan produk menggunakan bahasa yang mampu dimengerti oleh siswa serta terdapat kalimat petunjuk yang membimbing siswa dalam setiap tahapan melakukan praktikum. Pengembangan produk tersebut bertujuan untuk mengatasi permasalahan yang ditemukan pada tahapan analisis kebutuhan. Pada uji keterlaksanaan diperoleh bahwa petunjuk praktikum IPA berbasis model inkuiri terbimbing termasuk dalam kategori sangat terlaksana. Berdasarkan hasil yang diperoleh pada uji keterbacaan dan keterlaksanaan, petunjuk praktikum IPA berbasis model inkuiri terbimbing dapat dikatakan praktis digunakan dalam kegiatan belajar.

Hasil kepraktisan petunjuk praktikum IPA berbasis model inkuiri terbimbing disebabkan oleh guru yang mudah dalam memanfaatkan petunjuk praktikum IPA dalam proses pembelajaran. Begitu juga alat serta bahan yang digunakan dalam proses praktikum telah tersedia dalam laboratorium sekolah, sehingga memudahkan dalam proses praktikum. Respon yang sama juga diberikan oleh siswa sebagai pengguna petunjuk praktikum IPA berbasis model inkuiri terbimbing. 
Pembelajaran

dengan menggunakan sebuah perangkat (petunjuk praktikum) berbasis model inkuiri akan memberikan kesempatan kepada siswa untuk mengkonstruksi pengetahuan sendiri, menggunakan konsep-konsep yang sudah dimiliki untuk memecahkan masalah yang dihadapi. Hal ini serupa dengan hasil penelitian yang dilakukan oleh Rapi (2018) yang mendapatkan hasil (1) terdapat perbedaan keterampilan proses IPA, sikap ilmiah, dan hasil belajar IPA secara bersama-sama antara siswa yang difasilitasi perangkat pembelajaran berbasis inkuiri dengan PBK dan yang difasilitasi pembelajaran konvensional, (2) nilai ratarata keterampilan proses IPA, sikap ilmiah, dan hasil belajar IPA siswa yang difasilitasi perangkat pembelajaran inkuiri dan PBK lebih tinggi daripada yang difasilitasi perangkat pembelajaran konvensional. Rapi (2018) juga mengatakan perangkat pembelajaran berbasis inkuiri juga dapat memberikan kesempatan kepada siswa untuk bekerja seperti ilmuan yakni merumuskan hipotesis, menggali informasi, merancang dan melakukan percobaan, dan mengkomunikasikan hasil percobaan.

Beberapa kendala yang dialami siswa dalam pembelajaran menggunakan produk hasil pengembangan adalah sebagian siswa saat melakukan eksperimen tidak bisa menyelesaikan dengan tepat waktu karena keterampilan siswa dalam menggunakan alat serta melakukan eksperimen kurang terlatih. Selain itu, kemampuan siswa dalam membuat rumusan masalah serta hipotesis dalam tahapan praktikum masih cenderung kurang terlihat dari hasil respon siswa pada Tabel 3. Hal tu disebabkan karena siswa tidak mengerti arti dari rumusan masalah serta hipotesis. Selain itu, siswa cenderung hanya fokus pada tahap melakukan percobaan saja demi mendapatkan hasil untuk dapat melengkapi tabel pengamatan. Kendala lain yang muncul pada saat pembelajaran menggunakan produk hasil pegembangan adalah masih rendahnya kemampuan siswa, sehingga pada saat melengkapi tabel hasil pengamatan praktikum siswa masih membutuhkan waktu yang lama serta bimbingan yang ekstra dari guru. Hal itu terlihat dari respon siswa pada Tabel 3.

Adapun implikasi sekaligus solusi untuk mengatasi permasalahan tersebut, diantaranya guru harus lebih sering membimbing siswa dalam melakukan eksperimen serta melatih siswa untuk menggunakan alat-alat laboratorium, sehingga pada eksperimen berikutnya siswa sudah terbiasa dan dapat menyelesaikan praktikum sesuai dengan waktu yang telah ditentukan. Selain itu, pada petunjuk praktikum harus lebih dilengkapi dengan kalimat perintah yang jelas disertai dengan simbol yang menarik yang berfungsi untuk menuntun siswa dalam membuat rumusan masalah serta hipotesis. Pada pengembangan petunjuk praktikum berikutnya penting untuk memahami dengan benar kondisi siswa pada analisis kebutuhan sehingga pada saat pengembangan produk dapat ditentukan tingkat kesulitan ataupun tingkat keterbimbingan yang cocok sesuai dengan kemampuan siswa.

\section{SIMPULAN DAN SARAN}

Simpulan dari penelitian ini adalah petunjuk praktikum IPA berbasis model inkuri terbimbing untuk siswa SMP/MTs kelas VIII telah dikategorikan praktis sesuai dengan hasil analisis data uji keterbacaan dan uji keterlaksanaan. Adapun hal-hal yang dapat direkomendasikan dalam penelitian ini terutama bagi guru dan peneliti lainnya adalah (1) guru perlu melatih kebiasaan siswa membuat rumusan masalah serta hipotesis sehingga siswa lebih percaya diri dalam mengikuti kegiatan praktikum, (2) guru perlu memperbanyak melatih siswa dalam menggunakan alat-alat laboratorium, (3) guru diharapkan memberikan instruksi dan pengarahan yang jelas kepada siswa terkait kegiatan pada petunjuk praktikum, (4) perbanyak penggunaan alat-alat laboratorium dalam pengembangan sebuah petunjuk praktikum IPA. Hal itu akan membantu siswa untuk mengenal lebih jauh peralatan labaratorium, (5) Lengkapi setiap tahapan praktikum dengan kalimat perintah yang jelas. Bila perlu sertakan simbol yang menarik perhatian siswa untuk membaca setiap kalimat perintah pada setiap tahapan 
praktikum (6) pelajari dengan benar kondisi siswa pada tahapan analisis kebutuhan, sehingga pada penelitian berikutnya bisa dipertimbangkan tingkat kesulitan ataupun tingkat keterbimbingan dalam pembuatan produk.

\section{DAFTAR PUSTAKA}

Arikunto, S., 2006. Prosedur Penelitian Suatu Pendekatan Praktik. Jakarta: PT. Rineka Cipta

Depdiknas. 2003. Undang-Undang Republik Indonesia Nomor 20 Tahun 2003 tentang Sistem Pendidikan Nasional. Jakarta.

Djamarah, S. B \& Zain, A. 2006. Strategi Belajar Mengajar. Jakarta: PT. Rineka Cipta.

Fransiska, L., Subagia, W., \& Sarini, P. 2019. Pengaruh Model Pembelajaran Guided Discovery Terhadap Keterampilan Proses Sains Siswa SMP Negeri 3 Sukasada. Jurnal Pendidikan dan Pembelajaran Sains Indonesia 1(1): 13-24

Marheni, N.P \& Suardana, I. N. 2014. Pembelajaran Inkuiri Terbimbing Berbasis Budaya Lokal pada Pembelajaran Sains Kimia SMP. Jurnal Wahana dan Sains 8(2): 87100

Novianti, N. 2017. Upaya Meningkatkan Keterampilan proses Sains Siswa Pada Pembelajaran IPA Tipe Webbed dengan Pendekatan Inkuiri. Seminar Nasional Pendidikan: 74-78

Pariatna, I W. J, Sudria, I. B. N, \& Wasono, N. K. 2015. Pengembangan Perangkat Pembelajaran Inkuirir Terbimbing Pada Topik Laju Reaksi. Jurnal Wahana Matematika dan Sains 9(1): 38-50.

Payudi, Etikanto, C., Fadiawati, N \& Suyatna, A. 2017. The Development of Student Worksheet Assisted by Interactive Multimedia of Photoelektric Effect to Build Science Process Skills. International Journal of Science and Applied Science: Conference Series 2(1): 273-282.

Prasetyo, E. 2015. Ternyata Penelitian Itu Mudah. Lumajang: eduNomi.
Permendikbud. 2016. Peraturan Menteri Pendidikan Nasional Nomor 21 TentangStandar Isi Untuk Satuan Pendidikan Dasar dan Menengah. Jakarta.

Permendikbud. 2016. Peraturan Menteri Pendidikan Nasional Nomor 22 TentangStandar Proses Untuk Satuan Pendidikan Dasar dan Menengah. Jakarta.

Permendikbud. 2014. Peraturan Menteri Pendidikan Nasional Nomor 103 TentangPembelajaran Pada pendidikan Dasar dan Pendidikan Menengah. Jakarta.

Rahayu, A.H \& Anggraeni, P. 2017. Analisis profil keterampilan Proses Sains Siswa Sekolah dasar di kabupaten Sumedang. Jurnal Pesona Dasar 5(2): 22-33.

Rapi, N.K. 2018. Pengembangan Perangkat Pembelajaran IPA Berbasis Inkuiri untuk Meningkatkan Keterampilan Proses, Sikap Ilmiah, dan Hasil Belajar IPA di SMP. Artikel IImiah (online): 224-231.

Sadia, I. W. 2014. Model-Model Pembelajaran Sains Konstruktivistik. Yogyakarta: Graha IImu.

Simamora, A. H \& Sudarma, I. K. 2017. Analisis Perangkat Pembelajaran Kurikulum 2013 di Sekolah Dasar. Journal of Education Technology 1(2): 149-155.

Sofiani, D., Nurhayati, Sunarya, $Y$ \& Suryatna, A. 2017. Development of Guided inquiry-Based Laboratory Worksheet on Topic of Heat of Combustion. Journal of Physics: 1-6.

Suastra, I. W. 2013. Pembelajaran Sains Terkini. Singaraja: Universitas Pendidikan Ganesha.

Suryani, N \& Agung, L. 2012. Strategi Belajar Mengajar. Yogyakarta: Penerbit Ombak.

Trianto. 2010. Model Pembelajaran Terpadu. Jakarta: Bumi Aksara

Wahyuni, K. A. S. 2016. Pengembangan LKS IPA Terintegrasi Siswa SMP Kelas VII dengan Tema Panas Bumi dan Lingkunganku. Prosiding Seminar Nasional MIPA: 205-218. 
Wardani, K. S. K., Sadia, I. W., \& Suastra, I. W. 2016. Pengembangan Perangkat Pembelajaran IPA Terpadu dengan Setting Inquiry Laboratorium Bermuatan Content Local genius untuk Meningkatkan Pemahaman Konsep dan Keterampilan Proses Sains Siswa SMP. Proding Seminar Nasional MIPA: 230-239. 